\author{
断層の非一様すべり破壊モデルから算定される短周期レベルと \\ 半経験的波形合成法による強震動予測のための震源断層のモデル化
}

\title{
SHORT-PERIOD SOURCE SPECTRA INFERRED FROM VARIABLE-SLIP RUPTURE MODELS AND MODELING OF EARTHQUAKE FAULTS FOR STRONG MOTION PREDICTION BY SEMI-EMPIRICAL METHOD
}

\author{
壇 一 男*, 渡辺基史**, 佐藤俊明***, 石井 透* \\ Kazuo DAN, Motofumi WATANABE, Toshiaki SATO \\ and Toru ISHII
}

\begin{abstract}
The effective stresses on the asperities and backgrounds of the faults should be evaluated in the strong motion prediction for future earthquakes. First, short-period source spectra were inferred from variable-slip rupture models for 12 earthquakes of $M_{W} 5.6$ to 7.2 in lands and for 6 large earthquakes of $M_{W} 7.2$ to 8.1 in subduction zones. Then, the slip amounts and effective stresses on the asperities and backgrounds were evaluated based on the short-period source spectra inferred in this paper. Here, the statistics of the variable-slip rupture models were adopted that described the ratios of the areas, slip amounts, and effective stresses on the asperities to those on the entire fault. Finally, modeling of faults were presented for two types of destructive earthquakes of $M_{W} 7.3$ in lands and of $M_{W} 8.3$ in subduction zones with the effective stresses 126 bars and 83 bars, respectively, on the asperities.
\end{abstract}

Keywords : strong motion, source spectrum, variable-slip rupture model, asperity model, effective stress, semi-empirical method

強震動, 震源スペクトル, 非一様すべり破壞モデル, アスペリティモデル, 実効応力, 半経験的波形合成法

\section{1.はじめに}

構造物の耐震設計や耐震診断、あるいは各種防災対策を考える 上で、想定地震による強震動の予測結果は最も基礎的な資料であ る。壇・佐藤 $(1998)^{1)}$ は、1995 年兵庫県南部地震 $\left(M_{J M A} 7.2\right)$ 以来 その重要性が強く認識されてきている断層破壊の複雑さを、有力 な強震動予測手法のひとつである半経験的波形合成法に、直接的 かつ定量的に組み込み、1923 年関東地震 $\left(M_{J M A} 7.9\right)$ による強震動 を再現した。その結果、強震動の予測のためには、長周期地震動 のレベルを規定する地震モーメントのみならず、短周期地震動の レベル(短周期領域における加速度震源スペクトルのレベルで、以 下、短周期レベルとよぶ)を規定する断層の大きさと実効応力をど う設定するかが重要であることを示した。

その後、強震動予測を目的として、断層の非一様すべり破壊モ デルの統計的特質の抽出が、Somerville et al. $(1999)^{2)}$ および石井 . 他 $(2000)^{3)}$ により行われた。このうち、Somerville et al. (1999) は、統計的特質を、大地震の断層面上で相対的に最終すべり量が 大きな領域、すなわちアスペリティの面積とそこにおける最終す ベり量で表す方法と、最終すべり量の波数スペクトルで表す方法 とを用いているが、研究成果の具体的な強震動予測への適用は 行っていない。そこで、入倉・釜江 $(1999)^{4)}$ は、アスペリティの
面積と最終すべり量で震源モデルを表す方法による結果を 1948 年 福井地震 $\left(M_{J M A} 7.1\right)$ に適用して、理論的方法と半経験的方法を組 み合わせたハイブリッド法により強震動を計算し、家屋の全壤率 分布とよく対応する結果を得ている。強震動予測のためには、ア スペリティの面積と最終すべり量のみならず、実効応力が必要と なるが、入倉・釜江 (1999) 4 は) は、各アスペリティを周囲が拘束さ れた円形クラックに置換し、アスペリティの面積と最終すべり量 から算定した応力降下量を実効応力としている。これは、応力負 担が非常に小さい、もしくは応力負担が 0 の背景領域を有する通 常のアスペリティモデル (Das and Kostrov, 1986); Boatwright, 19886) など) とは異なる力学条件を設定していることになる。

一方、石井 ·他 $(2000)^{3)}$ は、統計的特質を、大地震の断層面上 で相対的に地震モーメントの解放量が大きな領域、すなわち主破 壞領域の面積とそこに打ける地震モーメントで表した。その後、 石井・佐藤 $(2000 \mathrm{a})^{7)}$ は、この結果を 1985 年メキシコ Michoacan 地 震 $\left(M_{S} 8.1\right)$ に適用して、半経験的波形合成法により強震動を計算 し、強震記録とよく対応する計算結果を得ている。この場合も、 入倉・釜江 $(1999)^{4)}$ による福井地震の強震動予測と同じく、各主 破壊領域の実効応力が必要となるが、石井・佐藤 $(2000 \mathrm{a})^{7)}$ は、背 景領域を有するアスペリティモデルを念頭に、円形クラックの式
* 清水建設侏和泉研究室 博士 (工学)

** 清水建設(陎)和泉研究室工修

*** 清水建設(侏和泉研究室工博
Izumi Research Institute, Shimizu Corporation, Dr. Eng.

Izumi Research Institute, Shimizu Corporation, M. Eng.

Izumi Research Institute, Shimizu Corporation, Dr. Eng. 
で算定した応力降下量を経験的に補正し、その值を実効応力とし て用いている。

以上、述べたように、断層の非一様すべり破壊モデルの統計的 特質の抽出結果に基づいて強震動予測を行うには、各アスペり ティもしくは各主破壊領域の実効応力の算定が不可欠であり、そ の妥当性については、個々の地震の強震動シミュレーションを積 み重ねて検証するという方法をとっているのが現状である。

このように、強震動予測で不可欠な各アスペリティもしくは各 主破壊領域の実効応力の妥当性が事前に検証できないのは、 Somerville et al. (1999) 2) や石井・他 (2000) ${ }^{3)}$ により抽出された断層 の非一様すべり破壊モデルの統計的特質がどのような力学モデル に対応するものかが明らかにされていないこと、および各地震の 短周期レベルが断層の非一様すべり破壊モデルの統計的特質とし て抽出されていないためである。

このうち、抽出された統計的特質と力学モデルとの対応につい て、最近、入倉 $(2000)^{8)}$ は、アスペリティの面積と最終すべり量 からアスペリティにおける地震モーメントを計算し、各アスペリ ティの実効応力が一定となるように、アスペリティの最終すべり 量を再配分することを提案している。入倉 $(2000)^{8)}$ は、この場合 にも、周囲が拘束された円形クラックの式で算定される応力降下 量をアスペリティにおける実効応力としているが、その值は、断 層面上のすべり分布から動力学的に直接推定された静的応力降下 量とよく対応していると述べている。

一方、震源の力学モデルと短周期レベルとの関係に関する研究 としては、Papageorgiou (1988) ${ }^{9)}$ による同形の複数の円形クラック から構成されるスペシフィックバリアモデル (Papageorgiou and Aki, 1983) ${ }^{10)}$ の震源スペクトルの定式化、Gusev (1989) ${ }^{11)}$ による複 数のアスペリティから構成されるアスペリティモデルの短周期レ ベルの定式化などがある。このうち、スペシフィックバリアモデ ルでは円形クラック以外の領域におけるすべり量は０として、ア スペリティモデルではアスペリティ以外の領域 (背景領域)におけ る応力負担は 0 として、震源スペクトルもしくは短周期レベルが 定式化されている。しかしながら、実際の地震の震源同定によっ て得られた非一様すべり破壊モデルでは、統計処理により背景領 域とされた部分における最終すべり量や最大すべり速度は 0 では なく、上述したスペシフィックバリアモデルやアスペリティモデ ルとは異なる力学的な状態にあると考えられる。

強震動予測に際しては、このような震源における複雑な力学状 態を把握し、断層面において適切な実効応力を設定する必要があ るが、現時点では、想定地震のみならず、過去に起こった地震に ついてさえも、その力学状態は完全には解明されていない。そこ で、本論文では、半経験的波形合成法による強震動予測で必要と なる実効応力を算定することを目的に、上述した Somerville et al. $(1999)^{2)}$ や石井・他 $(2000)^{3)}$ と同様に、震源をアスペリティと背景 領域とから構成される簡便なモデルで表現し、そのモデルに与え るべき最終すべり量と実効応力を断層全体の地震モーメントと短 周期レベルで規定することを考えた。

そのために、2 章では、これまでに同定されている 12 の内陸地 震および 6 つの海溝付近の地震の非一様すべり破壊モデルから短 周期レベルを算定し、その統計的特質を調べた。ついで、3 章で は、Somerville et al. (1999) 2) や石井・他 (2000) ${ }^{3)}$ により抽出された 震源断層の統計的特質を有し、かつ非一様すべり破壊モデルから
算定した短周期レベルを有する震源モデルを考え、各アスペリ ティもしくは各主破壊領域における実効応力の算定式を示した。 また、4 章では、地震モーメントと短周期レベルで規定される本 論文での震源モデルと、Papageorgiou (1988) ${ }^{9)}$ や Gusev (1989) ${ }^{11)}$ な どによる既往の震源モデルとの関係について調べた。最後に、5 章では、この算定式に基づいて、わが国に甚大な被害をもたらし てきた内陸の大地震および海溝付近の巨大地震の震源のモデル化 の例を示し、考察を行った。

なお、以下では、Somerville et al. (1999) 2) が定義したアスペリ ティおよび石井・他 $(2000)^{3)}$ が定義した主破壊領域とも、アスペ リティとよぶこととする。

\section{2. 非一樣すべり破壊モデルから算定される短周期レベル}

\section{1 短周期レベルの算定式}

断層の非一様すべり破壊モデルから短周期レベルを算定するに あたっては、壇・佐藤 $(1998)^{1)}$ が導いた下式を用いた。

$$
\begin{aligned}
& A=4 \pi\left[\Sigma_{p q}\left(\lambda_{p q} \sigma_{p q} \beta_{p q}^{2}\right)^{2}\right]^{1 / 2} \\
& \sigma_{p q}=\rho_{p q} \beta_{p q} V_{p q} / 2
\end{aligned}
$$

ここに、 $p q$ は $(p, q)$ 番目の要素断層に関する量であることを示す 添え字、 $\Sigma_{p q}$ は $p q$ に関する総和、入は要素断層を面積が等しい 円形断層に置換したときの半径、 $\sigma$ は実効応力、 $\beta$ は媒質の $S$ 波 速度、 $\rho$ は媒質の密度、 $V$ は震源同定により得られた最大すべり 速度である。ただし、本論文で用いる各地震の非一様すべり破壤 モデルのすべり速度時間関数は、壇・佐藤 $(1998)^{1)}$ が用いた1923 年関東地震のすべり速度時間関数とは異なって、各タイムウィン ドウが重なることがなく一定の時間間隔ですべり速度が 0 となる ものもあり、この場合、最大すべり速度は過大評価されていると 考えられる。そこで、ここでは、この問題を回避するために、石 井・他 $(2000)^{3)}$ および石井・佐藤 $(2000 \mathrm{a})^{7)}$ にしたがい、すべり時 間関数が最終すべり量の $10 \sim 70 \%$ となる時間の平均速度を $V$ と して用いた。なお、（2）式で示されるように、本論文での実効応 力 $\sigma$ は、上述した最大すべり速度 $V$ に比例する量である。

(1) 式および (2) 式で算定される短周期レベルの妥当性は、半経 験的波形合成法に基づく、Dan and Sato (1998) ${ }^{12)}$ による 1979 年米 国 Imperial Valley 地震 $\left(M_{L} 6.6\right)$ の断層近傍の加速度記録の再現、 Dan and Sato (1999) $)^{13)}$ による 1985 年 Michoacan 地震 $\left(M_{S} 8.1\right)$ の震 央域内の加速度記録の再現、壇 - 佐藤 $(1999)^{14)}$ による 1993 年北 海道南西沖地震 $(M, 7.8)$ の JMA 札幌および JMA 秋田における加 速度記録の再現を通じて、間接的に示されていると考えられる。 そこで、本論文では、半経験的波形合成法による強震動予測で必 要となる実効応力を算定することを目的としていることから、 (1) 式および (2) 式で算定される短周期レベルは妥当であるとし て、以下の議論を進めることとした。

ただし、(1) 式は、各要素断層の震源スペクトルが $\omega^{-2}$ モデル (Aki, 1967 15); Brune, 197016) など) で表されると仮定した算定式で あり、この仮定に立脚して、長周期の地震記録を用いて同定され たすべり速度時間関数から各要素断層の短周期レベルを推定した ものである。また、実際の短周期地震動の励起には、最大すべり 速度だけではなく、破壊伝播速度の変化やメカニズムの変化も関 与している。したがって、(1) 式および (2) 式で算定される短周期 レベルとそれぞれの地震の加速度記録から求められる短周期レベ ルとを直接比較するなどの検証が別途必要である。 
さらに、(1) 式では、各要素断層から放出される短周期の地震 波は互いにランダムに重なり合うとして、断層全体の短周期レべ ルを各要素断層の短周期レベルの自乗和平方根で表している。し たがって、（1）式における短周期とは、震源において無相関な地 震動の周期、具体的には、アスペリティサイズに対応する時間幅 を有するパルス波 (例えば宮武, 1998) ${ }^{17}$ ) の卓越周期よりも短い周 期ということになる。一方、加速度記録のフーリエスペクトルに は、5 20 Hz より高い振動数領域で減少する特性、すなわち震源 スペクトルとしては $\omega^{-2}$ からさらに急峻に減少する特性が一般的 に見られ、そのような特性が現れる限界振動数は $f_{\text {max }}$ (例えば Hanks, 1982) ${ }^{18)}$ と呼ばれている。以上の 2 点から、(1) 式における 短周期とは、アスペリティサイズに対応する時間幅を有するパル ス波の卓越周期よりも短く、 $f_{\text {max }}$ に対応する周期よりも長い周期 ということになる。なお、 $f_{\text {max }}$ と断層破壞メカニズムとの関係に ついては現在も研究中であることから、本論文では、 $f_{\text {max }}$ は震源 断層のモデル化に際して考慮しないこととした。

\section{2 短周期レベルの算定結果}

前節で示した (1) 式および (2) 式を用いて算定した短周期レベル を、内陸地震と海溝付近の地震に分けて、モーメントマグニ チュード $M_{W}$ および地震モーメント $M_{0}$ とともに表 1 に示す。表 中、1923 年関東地震の非一様すべり破壊モデルの出典は Wald and Somerville (1995) ${ }^{19)}$ の結果であり、それ以外の地震については石 井・他 $(2000)^{3)}$ に記載されているものと同じである。なお、1993 年北海道南西沖地震は、海溝付近の地震に分類し、南北 2 つの断 層をそれぞれ別々に計算した結果と、合わせて計算した結果を示 している。

図 1 (a)には、横軸に地震モーメントをとって、内陸地震の短周 期レベルを○で、海溝付近の大地震㧍よび巨大地震の短周期レベ ルを・で示す。

Frankel (1995) ${ }^{20)}$ の研究によると、内陸地震である 1989 年米国 Loma Prieta 地震の本震と複数の余震の加速度フーリエスペクトル の短周期帯域の值は、地震モーメントの立方根 $M_{0}{ }^{1 / 3}$ でスケーリ ングできることがわかっている。これは、 $\omega^{-2}$ の震源スペクトル (Aki, 1967 ${ }^{15)}$; Brune, 1970 ${ }^{16)}$ など) で、臨界円振動数 $\omega_{c}$ が $M_{0}^{-1 / 3}$ に 比例するとした場合に対応し、これまでに行われたマグニチュー ド4〜7クラスの地震の記録の解析結果 (釜江・他, 199021); 佐藤 · 他, 199422); 加藤・他, 1998 23) など) とも整合している。そこで、こ こでは、眓 1 (a)に○で示した内陸地震の短周期レベルを $M_{0}{ }^{1 / 3}$ で スケーリングすることし、最小自乗法で定数を決めた。その結 果、下のような関係式が得られた。

$$
A\left[\text { dyne-cm } / \mathrm{s}^{2}\right]=2.46 \times 10^{17} \times M_{0}^{1 / 3}
$$

ここに、 $M_{0}$ の単位は dyne-cm である。図 1 (a) の太線は、上式に よるもので、回帰に用いた $3.5 \times 10^{24} \leqq M_{0}[$ dyne-cm $] \leqq 7.5 \times 10^{26}$ の 範囲は実線で、その外側は破線で示した。一方、海溝付近の地震 については、上式で算定される短周期レベルより若干小さくなっ ているようである。そこで、参考のために、図 1 (a) には、細線 で、上式による短周期レベルを 0.5 倍および 2 倍したものも示し ている。

以下、他の地震についても既往の研究で用いられている震源モ デルから短周期レベルを算定した。
表 1 断層の非一椂すべり破壊モデルから算定した短周期レベル

\begin{tabular}{llll} 
内陸地震 & $M_{W}$ & $\begin{array}{l}M_{0} \\
\text { dyne-cm }\end{array}$ & $\begin{array}{l}\text { dyne-cm/s } \\
\text { 1992 Landers, California }\end{array}$ \\
1978 Tabas, Iran & 7.18 & $7.50 \mathrm{E}+26$ & $1.15 \mathrm{E}+26$ \\
1989 Loma Prieta, California & 7.11 & $5.80 \mathrm{E}+26$ & $1.45 \mathrm{E}+26$ \\
1995 Hyogo-Ken Nambu, Japan & 6.92 & $3.00 \mathrm{E}+26$ & $1.70 \mathrm{E}+26$ \\
1983 Borah Peak, Idaho & 6.84 & $2.40 \mathrm{E}+26$ & $6.20 \mathrm{E}+25$ \\
1985 Nahanni, Dec 23, Canada & 6.72 & $1.50 \mathrm{E}+26$ & $1.81 \mathrm{E}+26$ \\
1994 Northridge, California & 6.63 & $1.10 \mathrm{E}+26$ & $1.80 \mathrm{E}+26$ \\
1985 Nahanni, Oct. 5, Canada & 6.60 & $1.00 \mathrm{E}+26$ & $2.81 \mathrm{E}+26$ \\
1979 Imperial Valley, California & 6.40 & $5.00 \mathrm{E}+25$ & $3.77 \mathrm{E}+25$ \\
1986 North Palm Springs, California & 6.10 & $1.80 \mathrm{E}+25$ & $7.40 \mathrm{E}+25$ \\
1987 Whittier Narrows, California & 5.93 & $1.00 \mathrm{E}+25$ & $9.88 \mathrm{E}+25$ \\
1979 Coyote Lake, California & 5.63 & $3.50 \mathrm{E}+24$ & $2.84 \mathrm{E}+25$ \\
海溝付近の地震 & & & \\
1985 Michoacan, Mexico & 8.05 & $1.50 \mathrm{E}+28$ & $4.16 \mathrm{E}+26$ \\
1923 Kanto, Japan & 7.86 & $7.80 \mathrm{E}+27$ & $2.38 \mathrm{E}+26$ \\
1993 Hokkaido Nansei-Oki, Japan & 7.62 & $3.40 \mathrm{E}+27$ & $2.14 \mathrm{E}+26$ \\
$\quad$ Hokkaido Nansei-Oki (North) & 7.47 & $2.04 \mathrm{E}+27$ & $1.56 \mathrm{E}+26$ \\
Hokkaido Nansei-Oki (South) & 7.36 & $1.36 \mathrm{E}+27$ & $1.46 \mathrm{E}+26$ \\
1979 Petatlan, Mexico & 7.38 & $1.50 \mathrm{E}+27$ & $8.14 \mathrm{E}+25$ \\
1985 Zihuatanejo, Mexico & 7.35 & $1.35 \mathrm{E}+27$ & $3.96 \mathrm{E}+26$ \\
1981 Playa Azul, Mexico & 7.17 & $7.14 \mathrm{E}+26$ & $5.19 \mathrm{E}+26$ \\
\hline & & & \\
& & &
\end{tabular}

まず、マグニチュード 6 前後のカリフォルニアの地震に対して は、Papageorgiou (1988) ${ }^{9)}$ が、同形の円形クラックの集合体で震源 を表したスペシフィックバリアモデル (Papageorgiou and Aki, 1983) ${ }^{10)}$ のパラメータを同定しており、その短周期レベルは下式 で算定できる。

$$
A=4 \pi^{2}\left[\Sigma_{n}\left(f_{c n}^{2} M_{0 n}\right)^{2}\right]^{1 / 2}
$$

ここに、 $n$ は $n$ 番目の円形クラックに関する量であることを示す 添え字、 $f_{c}$ は臨界振動数、 $\Sigma_{n}$ は $n$ に関する総和である。

また、1946 年南海地震、1995 年兵庫県南部地震、1948 年福井 地震の 3 つの地震については、それぞれ釜江 $(1996)^{24)}$ 、釜江・入 倉 $(1997)^{25)}$ 、入倉・釜江 $(1999)^{4)}$ が強震動シミュレーションに用 いた震源モデルがあり、各地震の短周期レベルは (1) 式で算定で きる。

図 1 (a)には、これらの結果も、それぞれ、々、田、ロ、○で示し ている。図より、既往の研究で用いられている震源モデルの短周 期レベルは (3) 式による值とほぼ対応していることがわかる。

以上、述べた短周期レベルは、震源モデルから算定したもので あるが、強震記録から短周期レベルを直接評価した研究も多く行 われている。このうち、釜江・他 $(1990)^{21)}$ は主に和歌山県の地震 の記録を、佐藤・他 $(1994)^{22)}$ は主に福島県沖の地震の記録を、加 藤・他 $(1998)^{23)}$ は福島県沖のプレート境界地震と関東直下のやや 媣発地震および南関東の浅い地震の記録を用いて、各地震の短周 期レベルを評価している。

図 1 (a)には、釜江・他 $(1990)^{21)}$ により評価された主に和歌山 県の地震の短周期レベルをマで、加藤・他 $(1998)^{23)}$ により評価さ れた南関東の浅い地震の短周期レベルを らの地震の短周期レベルは、モーメントマグニチュードが 4 -7 


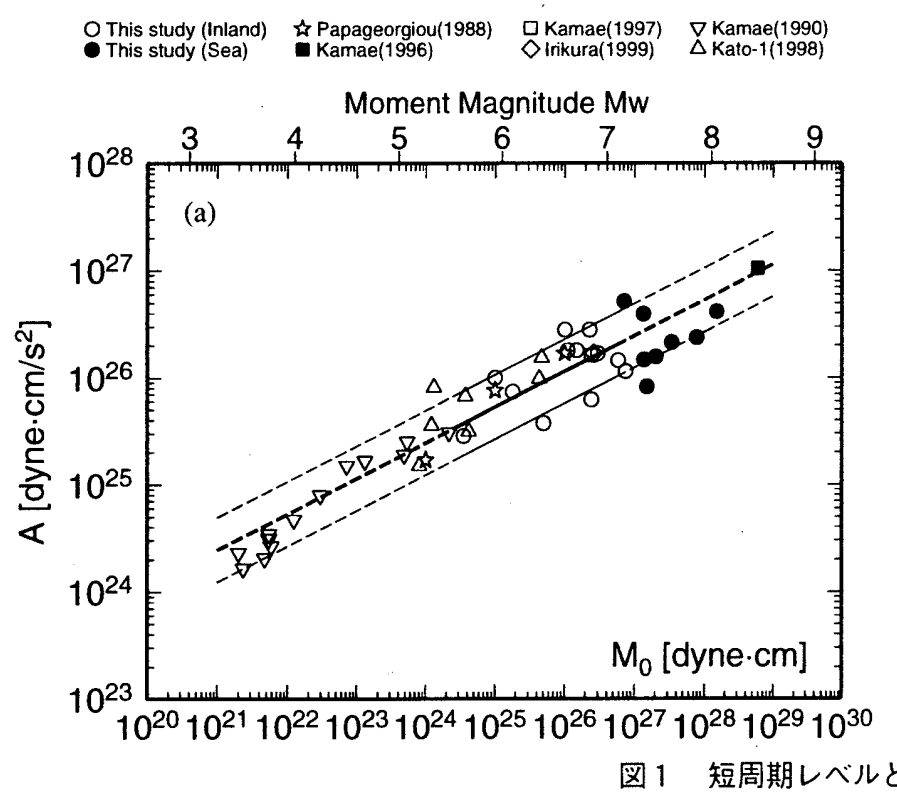

の広い範囲で (3) 式による值とほほ対応していることがわかる。

一方、図 1 (b) には、佐藤・他 $(1994)^{22)}$ や加藤・他 $(1998)^{23)}$ に より評価された福島県沖の地震の短周期レベルおよび加藤・他 $(1998)^{23)}$ により評価された関東直下のやや深発地震の短周期レべ ルを、それぞれ、○、、、听示す。図より、これらの地震の短 周期レベルは、(3) 式による值の1〜4 倍になっていることがわか る。

以上より、( 3 ) 式で示される地震モーメントと短周期レベルと の関係は、内陸の浅い地震や海溝付近の大地震および巨大地震に 対しては、妥当な関係式であるといえようが、加藤・他 $(1998)^{23)}$ も指摘しているように、この関係にはかなり地域差があるため、 実際の強震動予測に際しては、この震源域の特性を十分に考慮す る必要がある。

\section{3. 断層面におけるすべり量と実効応力の算定式}

本章では、はじめに、Somerville et al. (1999) ${ }^{2)}$ および石井・他 $(2000)^{3)}$ によって抽出された断層の非一様すべり破壊モデルの統 計的特質について述べたのち、アスペリティおよび背景領域のす ベり量と実効応力の算定式を示した。ついで、アスペリティが複 数存在する場合の各アスペリティのすべり量と実効応力の算定式 を示した。

Somerville et al. (1999) $)^{2)}$ は、将来起こるであろう内陸地震による 強震動を予測するための基礎資料を得ることを目的に、主にカリ フォルニアで起こった 15 の内陸地震 $\left(M_{W}=5.6\right.$ 7.2) の断層面にお けるすべり分布を統計処理し、アスペリティの総面積は断層全体 の面積の $22 \%$ を占めること、アスペリティの平均すべり量は断 層全体の平均すべり量の約 2 倍であることを示した。また、断層 全体の面積が断層全体の地震モーメントの $2 / 3$ 乗に比例するばか りではなく、アスペリティの面積もアスペリティの地震モーメン トの $2 / 3$ 乗に比例すること、すなわち、自己相似則が成り立って いることを示した。ここに、Somerville et al. $(1999)^{2)}$ が定義したア スペリティは、断層全体の平均すべり量の 1.5 倍以上のすべり量 を有する要素断層をもとに: 一定の手順に従って抽出された矩形 の領域である。

同様に、石井・他 $(2000)^{3)}$ は、15 の内陸地震 $\left(M_{W}=5.6 \sim 7.2\right)$ と
O Satoh(1994) $\triangle$ Kato-2(1998) $\square$ Kato-3(1998)

Moment Magnitude Mw

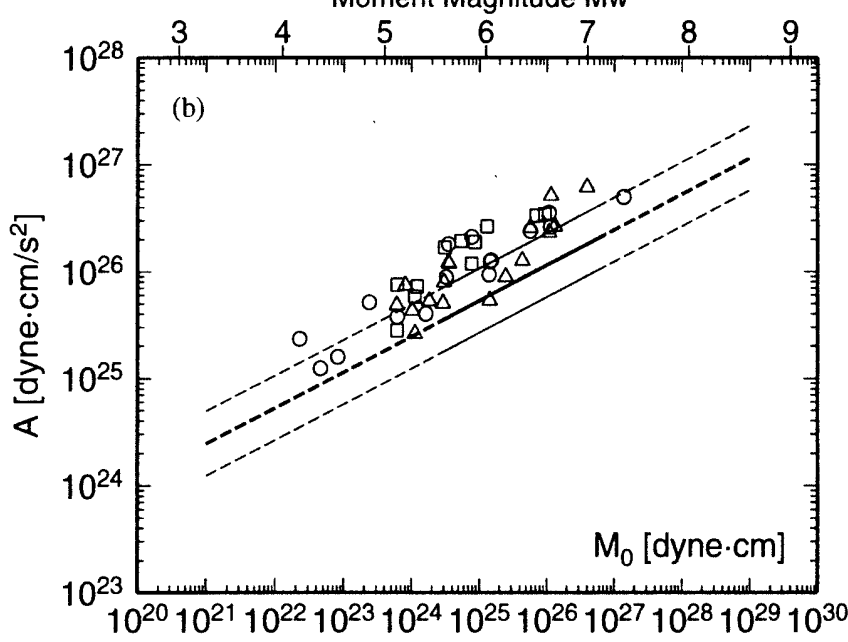

6 つの海溝付近の地震 $\left(M_{W}=7.2 \sim 8.1\right)$ の断層面における地震モー メント分布を統計処理し、アスペリティの総面積は断層全体の面 積の $35 \%$ を占めること、アスペリティの平均すべり量は断層全 体の平均すべり量の 2 倍であること、アスペリティにおける単位 面積当たりの短周期レベルは断層全体における単位面積当たりの 短周期レベルの 2 倍であることを示した。また、これらの統計的 特質は、内陸地震と海溝付近の地震で独立に検討されたが、両者 の間には有為な差はないと述べている。ここに、石井・他 $(2000)^{3)}$ が定義したアスペリティ(原著では主破壊領域) は、各要 素断層の地震モーメントを大きさ順に並べたとき、その累加値が 断層全体の地震モーメントの $70 \%$ となる要素断層群である。そ の後、石井・佐藤 $(2000 \mathrm{~b})^{26)}$ は、アスペリティとして抽出された 要素断層群を、互いに隣接する塊に分け、各アスペリティの統計 的特質を調ベた。その結果、第一アスペリティと第二アスペリ ティの面積比および第二アスペリティと第三アスペリティの面積 比は、ともに、平均的に $2: 1$ であること、断層全体の面積が断層 全体の地震モーメントの $2 / 3$ 乗に比例するばかりではなく、各ア スペリティの面積も各アスペリティの地震モーメントの $2 / 3$ 乗に 比例すること、すなわち、自己相似則が成り立っていることを示 した。

Somerville et al. $(1999)^{2)}$ および石井・他 $(2000)^{3)}$ による上記の結 果のうち、断層全体の諸量とアスペリティの諸量との関係は、一 般的に、以下のように書ける。ただし、実効応力に関する (7) 式 の $\gamma_{\sigma}$ は、Somerville et al. (1999) ${ }^{2)}$ の論文では求められていない。

$$
\begin{aligned}
& S_{\text {asp }}=\gamma_{S} S \\
& D_{\text {asp }}=\gamma_{D} D \\
& \sigma_{a s p}=\gamma_{\sigma} \sigma
\end{aligned}
$$

ここに、S は断層全体の面積、 $S_{\text {asp }}$ はアスペリティの総面積、 $D$ は断層全体における平均すべり量、 $D_{a s p}$ はアスペリティにおける 平均すべり量、 $\sigma$ は断層全体に扔ける平均実効応力、 $\sigma_{a s p}$ はアス ペリティにおける平均実効応力である。なお、単位面積当たりの 短周期レベルは、(1) 式で示したように、 $\sigma_{p q} \beta_{p q}^{2}$ に比例するが、 ここでは、簡単のために震源における $\beta_{p q}$ は要素断層によらず一 定と仮定した。 
いま、断層全体をアスペリティと背景領域に分け、それぞれの 領域に対応する量に asp および backの添字をつけると、以下の 9 つの関係式が成り立つ。

$$
\begin{array}{ll}
M_{0} & =\mu S D \\
M_{0} & =M_{0 a s p}+M_{0 b a c k} \\
M_{0 a s p} & =\mu S_{a s p} D_{a s p} \\
M_{0 b a c k} & =\mu S_{\text {back }} D_{\text {back }} \\
S & =S_{a s p}+S_{\text {back }} \\
\sigma & =\left(\sigma_{a s p} S_{a s p}+\sigma_{b a c k} S_{\text {back }}\right) / S \\
A & =\left[A_{\text {asp }}^{2}+A_{\text {back }}^{2}\right]^{1 / 2} \\
A_{\text {asp }} & =4 \pi\left(S_{\text {asp }} / \pi\right)^{1 / 2} \sigma_{a s p} \beta^{2} \\
A_{\text {back }} & =4 \pi\left(S_{\text {back }} / \pi\right)^{1 / 2} \sigma_{b a c k} \beta^{2}
\end{array}
$$

ここに、 $\mu$ は媒質の剪断剛性率である。上式は、媒質に関する量 である $\mu$ と $\beta$ を別にすれば、15個の変数を含んでいる。したがっ て、上の 9 つの式と (5) 式〜(7) 式の 3 つの式を組み合わせれば、 $M_{0} 、 S 、 A の 3 つ の$ 量を既知として、残りの 12 個の変数を決定す ることができる。このうち、アスペリティおよび背景領域の地震 モーメント、面積、平均すべり量は、

$$
\begin{array}{ll}
M_{0 a s p}=\gamma_{S} \gamma_{D} M_{0}, & M_{0 b a c k}=\left(1-\gamma_{S} \gamma_{D}\right) M_{0} \\
S_{a s p}=\gamma_{S} S, & S_{b a c k}=\left(1-\gamma_{S}\right) S \\
D_{a s p}=\gamma_{D} D, & D_{b a c k}=\left[\left(1-\gamma_{S} \dot{\gamma}_{D}\right) /\left(1-\gamma_{S}\right)\right] D
\end{array}
$$

と表され、実効応力は、

$$
\begin{aligned}
& \sigma_{a s p}=\left[\left(1-\gamma_{S}\right) \gamma_{\sigma} /\left(1-\gamma_{S} \gamma_{\sigma}\right)\right] \sigma_{b a c k} \\
& \sigma_{b a c k}=A\left[\gamma_{S}\left\{\left(1-\gamma_{S}\right) \gamma_{\sigma} /\left(1-\gamma_{S} \gamma_{\sigma}\right)\right\}^{2}+1-\gamma_{S}\right]^{-1 / 2} /\left[4(\pi S)^{1 / 2} \beta^{2}\right]
\end{aligned}
$$

と表される。

つぎに、アスペリティの数を $N$ とし、 $n$ 番目のアスペリティに 関する量に $n$ の添字をつけると、以下の関係式が成り立つ。

$$
\begin{array}{ll}
M_{0 a s p}=\Sigma_{n} M_{0 n}, & M_{0 n}=\mu S_{n} D_{n} \\
S_{\text {asp }}=\Sigma_{n} S_{n} & \\
A_{\text {asp }}=\left[\Sigma_{n} A_{n}{ }^{2}\right]^{1 / 2}, & A_{n}=4 \pi\left(S_{n} / \pi\right)^{1 / 2} \sigma_{n} \beta^{2}
\end{array}
$$

上式中、既知量は、 $M_{0 a s p} 、 S_{a s p} 、 A_{a s p}$ であるが、各アスペリティ の面積比はあらかじめ設定できるとすると、 $S_{n}$ も (23) 式の条件の もとに、すべて決定できる。したがって、未知量は、 $M_{0 n} 、 D_{n}$ 、 $A_{n} 、 \sigma_{n}$ の $4 n$ 個である。上の (22) 式と (24) 式は、 $2 n+2$ 個の式と なっているので、すべての未知量を確定するには、 $2 n-2$ 個の条

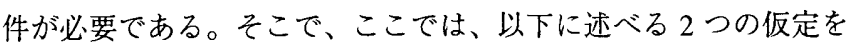
採用した。

壇・佐藤 $(1998)^{1)}$ が示した 1923 年関東地震の各要素断層の最終 すべり量 $D_{p q}$ と実効応力 $\sigma_{p q}$ との関係および Dan and Sato (1999) ${ }^{13)}$ が示した 1985 年 Michoacan 地震の各要素断層の最終すべり量 $D_{p q}$ と実効応力 $\sigma_{p q}$ との関係では、最終すべり量と実効応力とはほほ 比例関係があるものの、最終すべり量が大きいところ、すなわち アスペリティでは、実効応力はさほど大きくはなってない。した がって、アスペリティにおける実効応力は、アスペリティの平均 すべり量もしくは大きさによらず一定、すなわち、

$$
\sigma_{n}=\sigma_{a s p}^{*}
$$

と仮定した。

一方、周囲固定の円形クラックの場合、応力降下量 $\Delta \sigma_{c r}$ 、平均 すべり量 $D_{c r}$ 、断層面積 $S_{c r}$ との関係式 (Eshelby, 1957) 27) は、

$$
\Delta \sigma_{c r}=(7 \pi / 16) \mu D_{c r} /\left(S_{c r} / \pi\right)^{1 / 2}=1.37 \mu D_{c r} /\left(S_{c r} / \pi\right)^{1 / 2}
$$

であり、背景領域の応力負担が 0のアスペリティモデルの場合、 アスペリティに扔ける応力降下量 $\Delta \sigma_{a s p}$ 、平均すべり量 $D_{a s p}$ 、面 積 $S_{a s p}$ との平均的な関係式 (付録を参照) は、

$$
\Delta \sigma_{a s p}=(16 / 7 \pi) \mu D_{a s p} /\left(S_{a s p} / \pi\right)^{1 / 2}=0.728 \mu D_{a s p} /\left(S_{a s p} / \pi\right)^{1 / 2}
$$

と表される。そこで、ここでは、これらの関係式からの類推で、 各アスペリティの実効応力 $\sigma_{n}$ 、平均すべり量 $D_{n}$ 、断層面積 $S_{n}$ との間に、以下の関係を仮定した。

$$
\sigma_{n}=C \times \mu D_{n} /\left(S_{n} / \pi\right)^{1 / 2}
$$

ここに、Cは未定常数である。

以上、 2 つ.の仮定は、 $D_{n} \propto S_{n}{ }^{1 / 2}$ 、すなわち $S_{n} \propto M_{0 n}{ }^{2 / 3}$ となる自 己相似則を仮定していることと同じであり、このようなアスペリ

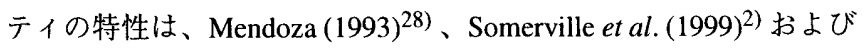
石井・佐藤 $(2000 b)^{26)}$ などによっても支持されている。

上の (25) 式と (28) 式および (22) 式〜 (24) 式、さらに、(15) 式の 関係を用いると、

$$
\begin{aligned}
& C=\left(\sigma_{a s p} \sum_{n} S_{n}{ }^{1.5}\right) /\left(\pi^{1 / 2} M_{0 a s p}\right) \\
& \sigma_{\text {asp }}^{*}=\sigma_{\text {asp }}
\end{aligned}
$$

を得る。このとき、各アスペリティの平均すべり量 $D_{n}$ と実効応 力 $\sigma_{n}$ は、下のように表される。

$$
\begin{aligned}
& D_{n}=\sigma_{a s p}\left(S_{n} / \pi\right)^{1 / 2} / \mu C \\
& \sigma_{n}=\sigma_{a s p}
\end{aligned}
$$

以上より、地震モーメント、断層面積、短周期レベル、および 各アスペリティの面積が設定できれば、各アスペリティおよび背 景領域の平均すべり量と実効応力が算定できることがわかった。

本章における式展開では、 $\sigma_{a s p}$ をアスペリティにおける平均実 効応力としているが、石井・他 (2000) ${ }^{3)}$ による (7) 式や (13) 式で は、

$$
\sigma_{a s p}=\left(\Sigma_{n} S_{n} \sigma_{n}\right) /\left(\Sigma_{n} S_{n}\right)
$$

と定義されているのに対し、本論文では、(15) 式、(23) 式、(24) 式を組み合わせると、

$$
\sigma_{a s p}=\left(\Sigma_{n} S_{n} \sigma_{n}^{2}\right)^{1 / 2} /\left(\Sigma_{n} S_{n}\right)^{1 / 2}
$$

で定義して扔り、平均化操作が異なっている。両者の相違をなく すには、(7) 式や (13) 式の $\sigma_{a s p}$ を(34) 式で定義し、再度 $\sigma_{a s p}$ と $\sigma$ の関係を調べればよいが、各アスペリティに対して自己相似則が 成り立っていれば、両者の相違はなくなる。

\section{4 . 既往の震源モデルとの関係}

前章における震源断層のモデル化では、地震モーメント、断層 面積、短周期レベル、および各アスペリティの面積を与条件とし ており、これらのパラメー夕間の物理的関係は考慮していない。 一方、既往の震源モデルでは、Papageorgiou (1988) ${ }^{9)} や$ Gusev $(1989)^{11)}$ の研究で示されているように、短周期レベルが、地震 モーメント、断篔面積、および各円形クラックもしくは各アスペ リティの面積により規定されている。この違いは、クラックやア スペリティに扔ける応力降下量が平均すべり量と面積で一意に決 まるのに対して、本論文では、短周期レベルを規定することによ り、アスペリティにおける実効応力と平均すべり量および面積を つなぐ常数 $C$ を末定常数として逆算していることによる。 
そこで、本章では、各アスペリティ間の相互作用の有無を考慮 しながら、短周期レベルから逆算される常数 $C$ がどのような性質 を有しているかを考察し、本論文の震源モデルと既往の震源モデ ルとの関係を調べた。

具体的には、図 2 の (a) に示したように、アスペリティが1個 の単アスペリティモデルと、(b) に示したように、面積が等しい $N$ 個の小アスペリティから構成される複アスペリティモデルを考 えた。ここに、複アスペリティモデルのアスペリティの総面積は (a) のアスペリティの面積と同じとし、すべての小アスペリティ が独立でその間に相互作用がない場合と、すべての小アスペリ ティが従属でその間に強い相互作用がある場合を考えた。また、 小アスペリティ間に強い相互作用がある場合には、小アスペリ ティが方形状に 2 方向に並んでいるとした。さらに、複合モデル として、 $N$ 個の小アスペリティが $N^{\gamma}$ 個ずつ集まって、 $N^{1-\gamma}$ 個の 群を形成し、各々の群の中では小アスペリティ間の相互作用が強 く、群と群の間では相互作用がない状態を考えた。ここに、各群 の中では、小アスペリティが 2 方向に並んでいるときを考えた。 以下、上述した 4 つのモデルを、単アスペリティモデル、複アス ペリティ独立モデル、従属 2 方向配列モデル、従属 2 方向配列複 合モデルとよび、それぞれのモデルに関する量に、[1]、[N]、 $\left[N^{+}\right] 、\left[N^{\#+}\right]$ をつけこととした。

(1) 単アスペリティモデル

アスペリティが負担する力を $F_{a s p}[1]$ とおくと、アスペリティ の実効応力は $\sigma_{a s p}[1]$ 、それが作用する面積は $S_{a s p}[1]$ であるの で、

$$
F_{\text {asp }}[1]=S_{\text {asp }}[1] \sigma_{\text {asp }}[1]
$$

と表される。一方、アスペリティが外部から受ける力も $F_{a s p}[1]$ であるが、周囲の状態からそれを求めるのは、媒質や背景領域の 状態によって変わるため、容易ではない。そこで、ここでは、ガ ウスの定理とフックの法則を念頭に、アスペリティと外部との力 の授受は、アスペリティの外周を構成する線分の長さに比例して 行われると仮定した。いま、アスペリティと外部との力の授受に 関する比例常数、すなわち、外部接続線分の単位長さ当たりの単 位すべり量に対するバネ常数を $K$ とおくと、単アスペリティモデ ルでは、外部接続線分の長さは $4\left(S_{a s p}[1]\right)^{1 / 2}$ 、平均すべり量は $D_{a s p}[1]$ であるから、

$$
F_{\text {asp }}[1]=4 K\left(S_{a s p}[1]\right)^{1 / 2} D_{a s p}[1]
$$

と表される。アスペリティにおける平均すべり量と実効応力との 関係は、前節の (28) 式から、単アスペリティモデルの場合、

$$
\sigma_{a s p}[1]=C[1] \times \mu D_{a s p}[1] /\left(S_{a s p}[1] / \pi\right)^{1 / 2}
$$

と書ける。以上の 3 つの式から、

$$
C[1]=4 K /\left(\mu \pi^{1 / 2}\right)
$$

の関係を得る。

(2) 複アスペリティ独立モデル

単アスペリティモデルと同様に、アスペリティが全体で負担す る力を $F_{a s p}[N]$ とおくと、 $N$ 個の小アスペリティの外部接続線分 の長さは $4 N\left(S_{a s p}[1] / N\right)^{1 / 2}$ 、平均すべり量は $D_{a s p}[N]$ であるから、

$$
\begin{aligned}
& F_{a s p}[N]=S_{a s p}[1] \sigma_{a s p}[N] \\
& F_{a s p}[N]=4 K N\left(S_{a s p}[1] / N\right)^{1 / 2} D_{a s p}[N]
\end{aligned}
$$

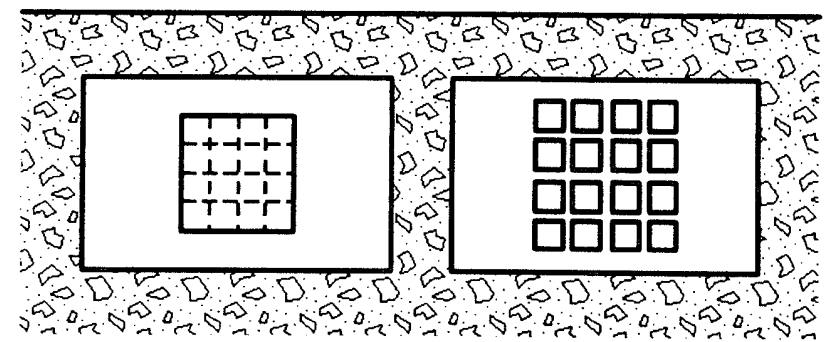

$\begin{array}{ll}\text { (a) 単アスペリティモデル } & \text { (b) 複アスペリティモデル }\end{array}$

図 2 相互作用の検討のためのアスペリティモデル

である。各小アスペリティにおける平均すべり量と実効応力との 関係は、

$$
\sigma_{\text {asp }}[N]=C[N] \times \mu D_{\text {asp }}[N] /\left(S_{\text {asp }}[1] / N \pi\right)^{1 / 2}
$$

であるから、

$$
C[N]=4 K /\left(\mu \pi^{1 / 2}\right)=C[1]
$$

の関係を得る。ここで、複アスペリティモデルにおける小アスペ リティの平均すべり量が、単スペリティモデルにおけるアスペリ ティの平均すべり量に等しいときを考えると、

$$
\begin{aligned}
& \sigma_{\text {asp }}[N]=N^{1 / 2} \times \sigma_{\text {asp }}[1] \\
& A_{\text {asp }}[N]=N^{1 / 2} \times A_{\text {asp }}[1]
\end{aligned}
$$

を得る。したがって、実効応力と短周期レベルは $N^{1 / 2}$ に比例する こととなり、Papageorgiou (1988) ${ }^{9)} や$ Gusev $(1989)^{11)}$ などの既往の 震源モデルに関する研究で示されている性質と全く同じ性質を示 す。

(3) 従属 2 万向配列モデル

このモデルは、 $N$ 個の小アスペリティが 2 方向に並び、すべて の小アスペリティが従属でその間に強い相互作用があるモデルで あるから、外部接続線分の長さは $4 N^{1 / 2}\left(S_{a s p}[1] / N\right)^{1 / 2 て ゙ あ る 。 こ の ~}$ 値を用いると、

$$
\begin{aligned}
& C\left[N^{+}\right]=N^{-1 / 2} \times C[1] \\
& \sigma_{a s p}\left[N^{+}\right]=\sigma_{a s p}[1] \\
& A_{\text {asp }}\left[N^{+}\right]=A_{\text {asp }}[1]
\end{aligned}
$$

の関係を得る。したがって、実効応力と短周期レベルは、小アス ペリティの個数によらず一定となり、一見、Papageorgiou (1988) や Gusev (1989)11) などの既往の震源モデルに関する研究で示され ている性質と全く異なる性質を示す。これは、ある小アスペリ ティの平均すべり量がその小アスペリティの実効応力だけではな く、前後左右の小アスペリティの実効応力の影響を大きく受けて いるため、すなわち小アスペリティ間の相互作用が断層全体にわ たって非常に強いためである。

このような震源モデルは、Boatwright $(1988)^{6)}$ が考察した4つの 震源モデルのうち、多数の小アスペリティが一体となって 1 個の クラックを形成しているモデルに対応しており、従属 2 方向配列 モデルは、 $N$ 個の小アスペリティが一体となって1個の大きなア スペリティを形成しているモデルということができる。

(4) 従属 2 方向配列複合モデル

相互作用の強い $N^{\gamma}$ 個の小アスペリティが 2 方向に並んだ $1 つ の$ アスペリティ群の外部接続線分の長さは $4 N^{\gamma / 2}\left(S_{a s p}[1] / N\right)^{1 / 2}$ であ 
り、このような群が $N^{1-\gamma}$ 個あるから、全体の外部接続線分の長 さは $4 N^{1-\gamma / 2}\left(S_{a s p}[1] / N\right)^{1 / 2}$ となる。この值を用いて、従属 2 方向配 列モデルと同様の計算を行うと、

$$
\begin{aligned}
& C\left[N^{\#+}\right]=N^{-\gamma / 2} \times C[1] \\
& \sigma_{a s p}\left[N^{\#+}\right]=N^{(1-\gamma) / 2} \times \sigma_{a s p}[1] \\
& A_{a s p}\left[N^{\#+}\right]=N^{(1-\gamma) / 2} \times A_{a s p}[1]
\end{aligned}
$$

の関係を得る。

相互作用の強い小アスペリティと小アスペリティに挟まれた背 景領域では、実効応力が小さくても、すべり量は小アスペリティ のすべり量と同じく大きくなっていると考えられる。このような 相互作用の強い 1 つのアスペリティ群は、断層面におけるすべり 量の分布だけからは、1 つの大きな独立したアスペリティと認識 され、Somerville et al. (1999) $)^{2}$ や石井・他 $(2000)^{3)}$ により抽出され たアスペリティは、このような独立したアスペリティであると推 察される。したがって、本章で設定している小アスペリティは、 厳密には、すべり量の大きな部分というより、実効応力の大きな 部分をさしていることになる。

(5) 既往の震源モデルへの置換

常数 $C$ の值は、上で見てきたように、小アスペリティ間の相互 作用の強弱に依存している。そこで、前章で扱った震源モデルに おける各アスペリティ間の相互作用を集約して、非常に強い相互 作用でつながっている $N^{\gamma}$ 個ずつのアスペリティ群を 1 つの独立 した大アスペリティに置換することを考えた。この場合の $\gamma$ は、

$$
C=N^{-\gamma / 2} \times C[1]
$$

を逆算して求められる。上式で逆算される $\gamma$ の值が小さいほどア スペリティ間の相互作用が小さく、 $\gamma$ の值が大きいほどアスペリ ティ間の相互作用が大きいことを示している。また、互いに独立 な大アスペリティに置換したとき、その個数は $N^{1-\gamma}$ 個となる。

$C[1]$ として、(26)式における円形クラックの值 $(7 \pi / 16)$ を用いれ ば、互いに独立な大クラックの集合体に置換したときの個数が求 められ、複数の円形クラックから構成される Papageorgiou and Aki $(1983)^{10)}$ によるスペシフィックバリアモデルや円形クラックの式 で算定される応力降下量をアスペリティにおける実効応力として いる入倉 $(2000)^{8)}$ による震源モデルと直接の比較ができる。ま た、C[1] として、(27) 式における背景領域の応力負担が 0 のアス ペリティモデルの值 $(16 / 7 \pi)$ を用いれば、互いに独立な大アスペ リティの集合体に置換したときの個数が求められ、複数の独立し たアスペリティから構成される Gusev (1989) ${ }^{11)}$ による複アスペリ ティモデルと直接の比較ができる。

次章で示す震源断層のモデルでは、(51) 式を用いて、互いに独 立な大クラックもしくは大アスペリティの集合体に置換したとき の個数も示した。

以上、本章での計算においては、ガウスの定理とフックの法則 を念頭に、小アスペリティと外部との力の授受は、小アスペリ ティの外周を構成する線分の長さに比例して行われ、強い相互作 用が存在する 2 つの小スペリティ間の向い合った線分の長さは 外部との力の授受に全く寄与しないと仮定した。また、小アスペ リティと背景領域との間の相互作用の強弱については考慮しな かった。これらの仮定の妥当性は理論的には検証されておらず、 今後、震源における複雑な力学状態の解明に関する研究が進展す
れば、このような相互作用のメカニズムが明らかになると期待さ れる。

また、本論文では、これまで、実効応力と応力降下量の違いを 明確に述べずに議論を展開してきたが、元来、実効応力とは、地 震の前後で断層面における応力が、初期応力 $\rightarrow$ 静止摩擦応力 $\rightarrow$ 動 摩擦応力 $\rightarrow$ 最終応力と変化していく段階における静止摩擦応力と 動摩擦応力の差のことであり、応力降下量とは初期応力と最終応 力の差のことである。本論文では、実効応力は最大すべり速度に 関連し、応力降下量は最終すべり量に関連する量として考えてい るため、用語を区別して使っている。しかしながら、一般的に は、両者は常に区別して使われているとは限らず、例えば、半経 験的波形合成法で経験的グリーン関数として用いる要素地震の断 層パラメー夕 (地震モーメント、断層面積、平均すべり量、応力 降下量もしくは実効応力など) を、Brune (1970) ${ }^{16)} の \omega^{-2}$ モデルに 基づいて、強震記録のフーリエスペクトルの長周期側の振幅値と 臨界周期の值から推定するときなどは、初期応力と静止摩擦応力 を同じ、動摩擦応力と最終応力を同じとの前提で、実効応力と応 力降下量は等しいと仮定し、円形クラックの (26) 式を適用する場 合がほとんどである。そこで、本論文で対象としている量が実効 応力かそれとも応力降下量かという観点から整理すると、第一 に、当然ながら、本論文で規定しようとしている量は、最大すべ り速度に対応する実効応力であって、最終すべり量と関連づけら れる応力降下量ではない、第二に、本章で述べたとおり、円形ク ラックもしくはアスペリティモデルの応力降下量の式に基づく既 往の震源モデルに置換した場合には、本論文の実効応力は応力降 下量と等しくなる、という2つの点が結論としていえる。

\section{5. 強震動予測のための震源断層のモデル化 5.1 震源断層のモデル化の概要}

3 章では、地震モーメント $M_{0}$ 、断層面積 $S$ 、短周期レベル $A$ 、 および各アスペリティの面積 $S_{n}$ が設定できれば、Somerville et al. $(1999)^{2)}$ や石井・他 $(2000)^{3)}$ により抽出された震源断層の統計的特 質に基ついて、各アスペリティの平均すべり量 $D_{n}$ と実効応力 $\sigma_{n}$ および背景領域の平均すべり量 $D_{b a c k}$ と実効応力 $\sigma_{b a c k}$ が算定でき ることを示した。実際の強震動の予測問題に際しては、地震モ一 メント、断層面積、短周期レベル、各アスペリティの面積は、詳 しい調査結果や研究成果を総合的に判断して、設定されるので、 ここでは、一般論として、これらの量の間の平均的な関係を用い て、以下のように設定することを考えた。

上記の 4 つのパラメータのうち断層面積については、内陸で発 生する大地震では活断層調查の結果や地震発生層の情報などか ら、海溝付近で発生する巨大地震ではプレートのブロック構造に 基づくプレート境界面の広がりや固着域の情報などから、ある程 度の予測が可能である。また、予測した断層面積をもとに、これ までに提案されている断層面積と地震モーメントとの関係 (佐藤, 198929); 金森, 199130); 武村, 1998 31); Somerville et al. 19992) など) か ら、その断層の平均的な地震モーメントが推定できる。さらに、 この地震モーメントをもとに、本論文の (3) 式を用いて、もしく は、短周期レベルと地震モーメントとの関係を示した図 1 から、 直接的に短周期レベルを設定することができる。

内陸の大地震や海漂付近の巨大地震は、その破壊領域が 1 つの セグメントもしくはブロックにとどまらずに、2 つ以上にわたっ 
ている場合がある。このような場合、断層全体の地震モーメント と短周期レベルの各セグメントもしくは各ブロックへの配分は、 ひとつひとつの想定地震について、詳しい調査結果や研究成果を 総合的に判断して、行われると思われるので、ここでは、自己相 似則を仮定して、地震モーメントは断層面積の 1.5 乗に比例する ように、短周期レベルはその自乗が断層面積に比例するように、 したがって各セグメントもしくは各ブロックの平均的な赛効応力 は一定となるように設定することを考えた。

一方、各セグメントもしくは各ブロックにおける各アスペリ ティの面積については、(15) 式に示したように、その総和を $\gamma_{S} S$ で設定することができる。ただし、 $S$ は、セグメントもしくはブ

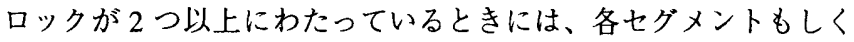
は各ブロックの面積と読み替える必要がある。石井・佐藤 $(2000 b)^{26)}$ の結果によると、第一アスペリティと第二アスペリ ティの面積比㧍よび第二アスペリティと第三アスペリティの面積 比は、ともに、平均的に 2:1 である。そこで、入倉・釜江 (1999) $)^{4)}$ が 1948 年福井地震の震源のモデル化で行ったのと同じように、2 個のアスペリティを考えるのであれば、 $\gamma_{S} S$ を第一アスペリティ と第二アスペリティに $2: 1$ で配分し、3 個のアスペリティを考え るのであれば、 $\gamma_{S} S$ を第一アスペリティから第三アスペリティに 4:2:1 で配分すれば、各セグメントもしくは各ブロックにおける 各アスペリティの面積を設定することができる。

\section{2 内陸で発生する大地震の震源モデルの例}

本節では、わが国に甚大な被害をもたらしてきた内陸の大地震 の震源のモデル化の例として、4 つのセグメントから構成される 総延長 $110 \mathrm{~km}$ の横ずれ断層を考えてみた。ここに、各セグメン トの長さは、 $25 \mathrm{~km} 、 35 \mathrm{~km} 、 15 \mathrm{~km} 、 35 \mathrm{~km}$ とし、震源における 媒質の剪断剛性率 $\mu$ は $3 \times 10^{11} \mathrm{dyne} / \mathrm{cm}^{2} 、 S$ 波速度 $\beta$ は $3.3 \mathrm{~km} / \mathrm{s}$ と した。渡辺・他 $(1998)^{32)}$ が、阿部 $(1990)^{33)}$ および Wells and Coppersmith (1994) 34 ) によるデー夕を整理した結果によると、横ず れ断層による内陸地震の場合、断層長さが約 $30 \mathrm{~km}$ までの地震で は、断層幅は断層長さとともに増大するが、断層長さが $30 \mathrm{~km}$.を 超えるような大地震では、地震発生層の厚さにより、幅は $15 \mathrm{~km}$ 程度で一定値をとる。そこで、ここでも、断層幅を $15 \mathrm{~km}$ とし た。したがって、断層面積は $1,650 \mathrm{~km}^{2}$ となる。

つぎに、この断層面積から、地震モーメントを設定するのであ るが、ここでは、これまでに起こった横ずれ断層による内陸地震 の断層面積と地震モーメントとの関係から設定してみる。図 3 に は、阿部 $(1990)^{33)} に よ る$ 横ずれ断層による内陸大地震の断層面積 と地震モーメントとの関係をロで、Wells and Coppersmith (1994) ${ }^{34)}$ に記載されている地震のうち横ずれ断層による内陸地震の断層面 積と地震モーメントとの関係を○で示す。この図から、断層面積 $1,650 \mathrm{~km}^{2}$ のとき、平均的な地震モーメントは $1 \times 10^{27}$ dyne-cm 前 後、モーメントマグニチュードで約 7.3 と推定できる。Somerville et al. $(1999)^{2)}$ が、主にカリフォルニアで起こった 15 の内陸地震 $\left(M_{W}=5.6 \sim 7.2\right)$ の断層面積と地震モーメントのデータから定めた 回帰式によれば、断層面積が $1,650 \mathrm{~km}^{2}$ のとき、地震モーメント は $0.65 \times 10^{27}$ dyne-cm 、モーメントマグニチュードで約 7.1 とな る。上述した推定值は、この值よりやや大きいが、Somerville $\boldsymbol{e t}$ $a l .(1999)^{2)}$ が回帰式の作成に用いたデー夕の範囲に含まれてい る。そこで、ここでは、地震モーメントとして、1×1027 dyne-cm

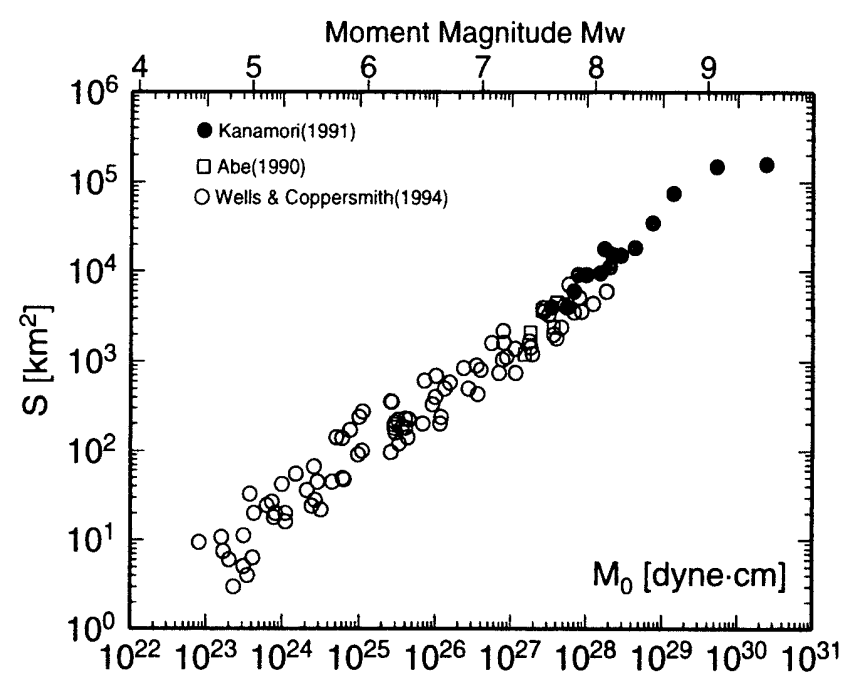

図 3 断層面積と地震モーメントとの関係

を採用することにした。この地震モーメントの值を (3) 式に代入 すると、平均的な短周期レベルは $2.46 \times 10^{26} \mathrm{dyne}-\mathrm{cm} / \mathrm{s}^{2}$ と算定で きる。

断層全体の地震モーメントと短周期レベルが設定できたので、 前節で述べたように、自己相似則を仮定して、地震モーメントと 短周期レベルを各セグメントに配分した。結果を表 2 に示す。

ここで、石井・他 $(2000)^{3)}$ により抽出された震源断層の統計的 特質に基づいて、

$$
\gamma_{S}=0.35, \gamma_{D}=2, \gamma_{\sigma}=2
$$

を採用すると、各セグメントにおけるアスペリティと背景領域の 地震モーメント、面積、平均すべり量、実効応力、短周期レベル が算定できる。

一方、各アスペリティの面積については、各セグメントで $2 つ$ のアスペリティを考え、第一アスペリティと第二アスペリティの 面積比を 2:1 とした。各セグメントにおいて、アスペリティの地 震モーメント $M_{0 a s p}$ と実効応力 $\sigma_{a s p}$ および各アスペリティの面積 $S_{n}$ が設定できたので、これらの値を用いて、(29) 式で常数 $C$ を求 めると、各セグメントに共通な值として、C=0.540 が得られた。 この値を (51) 式に代入すると、C[1] として円形クラックの值を用 いた場合、 $\gamma=0.899$ となり、いまの震源モデルの例は、 $N^{1-\gamma}=1.2 、$ すなわち 1 個の円形クラックに置換でき、C[1] としてアスペリ ティモデルの值を用いた場合、 $\gamma=0.287$ となり、 $N^{1-\gamma=4.4 、 す な わ ~}$ ち 4 個の独立なアスペリティから構成されるアスペリティモデル に置換できることがわかる。

3 章で示した算定式を用いて、各アスペリティの地震モーメン 卜、平均すべり量、短周期レベルを求めた。以上の結果をまとめ て表 2 にすべてのアスペリティを正方形としたうえで、地中の 断層変位が地表まで達するように、地震発生層の浅部にアスペリ ティを配置した例を図 4 に示す。

平均すべり量は、断層全体で $202 \mathrm{~cm}$ 、最も面積の大きなアス ペリテイ (asp3 および asp7) で $488 \mathrm{~cm}$ となっている。断層全体の 平均すべり量を、阿部 $(1990)^{33)}$ が整理した横ずれ断層による内陸 大地震の断層全体の平均すべり量と比較すると、1891 年濃尾地 震の $420 \mathrm{~cm}$ や 1990 年フイリピン Digdig 地震の $500 \mathrm{~cm}$ より小さ く、1976 年グアテマラ Motagua 地震の $200 \mathrm{~cm}$ や 1976 年中国 


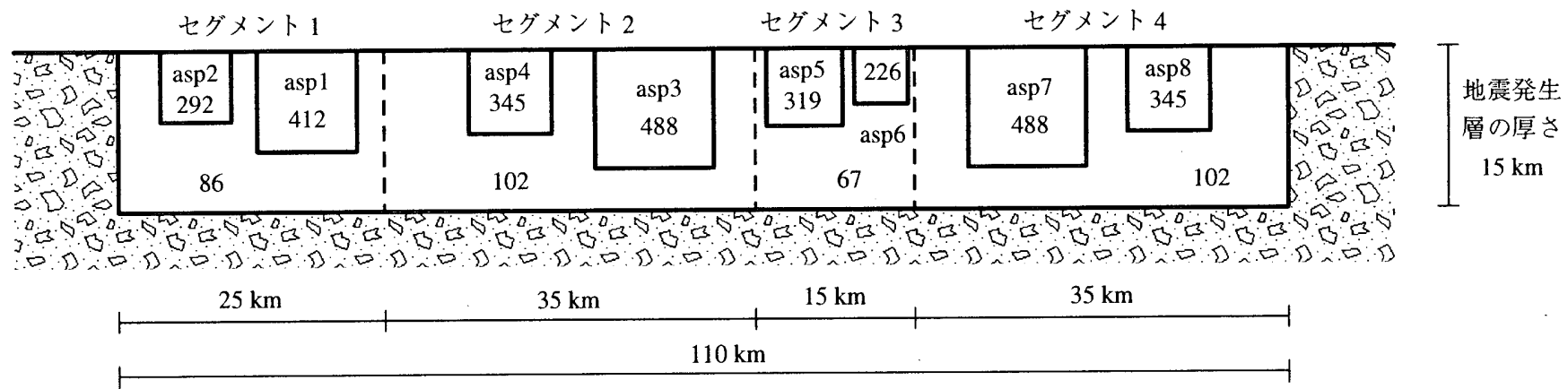

図 4 内陸で発生する大地震の震源モデルの例

断層面内の数字はすべり量 $(\mathrm{cm})$ である。また、実効応力は、アスペリティ (asp1〜asp8) で 126 bar、背景領域で 29 bar である。

Tangshan 地震の $270 \mathrm{~cm}$ とほぼ対応している。ここに、各地震の 断層長さは、濃尾地震が $80 \mathrm{~km}$ 、Digdig 地震が $120 \mathrm{~km}$ 、Motagua 地震が $250 \mathrm{~km}$ 、Tangshan 地震が $140 \mathrm{~km}$ である。断層全体の平均 すべり量やアスペリティにおける平均すべり量は、断層面積から 地震モーメントをどのように設定するかによって決まるのである が、地震モーメントの設定値は長周期地震動の振幅のみならず、 本論文で採用している (3) 式では地震モーメントの立方根と短周 期レベルが比例関係にあるため、短周期地震動の振幅にも影響を 与える。したがって、ここでは、一般論として、図 3 に示した平 均的な関係を用いて地震モーメントを設定したが、実際の強震動 の予測問題に際しては、想定する地震の地域性やトレンチ調査の 結果など十分に考慮する必要がある。

一方、各アスペリティの面積は生成される強震動パルスの卓越 周期と関係するが、これを、松島・川瀬 $(2000)^{35)}$ が 1995 年兵庫 県南部地震の強震動パルスのシミュレーションに際して同定した 4 個のアスペリティの大きさ、すなわち大きい 2 つのアスペリ ティの面積 $80 \mathrm{~km}^{2}$ および小さい 2 つのアスペリティの面積 22.5 $\mathrm{km}^{2}$ と比べると、両者はほほ対応した大きさとなっていることが わかる。

また、各アスペリティにより生成される強震動パルスの幅は、

\section{表 2 内陸で発生する大地震の震源パラメータの設定例}

\begin{tabular}{|c|c|c|c|c|c|}
\hline & $\begin{array}{l}M_{0} \\
\text { dyne-cm }\end{array}$ & $\begin{array}{l}S \\
\mathrm{~km}^{2}\end{array}$ & $\begin{array}{l}D \\
\mathrm{~cm}\end{array}$ & $\begin{array}{l}\sigma \\
\text { bar }\end{array}$ & $\begin{array}{l}A \\
\text { dyne-cm/s }\end{array}$ \\
\hline 断層全体 & $1.00 \times 10^{27}$ & 1650 & 202 & 63 & $2.46 \times 10^{26}$ \\
\hline \multirow[t]{4}{*}{ セグメント 1} & $2.09 \times 10^{26}$ & 375 & 186 & 63 & $1.17 \times 10^{26}$ \\
\hline & $1.08 \times 10^{26}$ & 88 & 412 & 126 & $0.91 \times 10^{26}$ \\
\hline & $0.38 \times 10^{26}$ & 44 & 292 & 126 & $0.65 \times 10^{26}$ \\
\hline & $0.63 \times 10^{26}$ & 244 & 86 & 29 & $0.35 \times 10^{26}$ \\
\hline セグメント 2 (全体) & $3.47 \times 10^{26}$ & 525 & 220 & 63 & $1.39 \times 10^{26}$ \\
\hline \multirow[t]{3}{*}{, } & $1.79 \times 10^{26}$ & 123 & 488 & 126 & $1.08 \times 10^{26}$ \\
\hline & $0.63 \times 10^{26}$ & 61 & 345 & 126 & $0.76 \times 10^{26}$ \\
\hline & $1.04 \times 10^{26}$ & 341 & 102 & 29 & $0.42 \times 10^{26}$ \\
\hline \multirow[t]{4}{*}{ セグメント 3} & $0.97 \times 10^{26}$ & 225 & 144 & 63 & $0.91 \times 10^{26}$ \\
\hline & $0.50 \times 10^{26}$ & 53 & 319 & 126 & $0.71 \times 10^{26}$ \\
\hline & $0.18 \times 10^{26}$ & 26 & 226 & 126 & $0.50 \times 10^{26}$ \\
\hline & $0.29 \times 10^{26}$ & 146 & 67 & 29 & $0.27 \times 10^{26}$ \\
\hline \multirow[t]{4}{*}{ セグメント 4} & $3.47 \times 10^{26}$ & 525 & 220 & 63 & $1.39 \times 10^{26}$ \\
\hline & $1.79 \times 10^{26}$ & 123 & 488 & $126^{\circ}$ & $1.08 \times 10^{26}$ \\
\hline & $0.63 \times 10^{26}$ & 61 & 345 & 126 & $0.76 \times 10^{26}$ \\
\hline & $1.04 \times 10^{26}$ & 341 & 102 & 29 & $0.42 \times 10^{26}$ \\
\hline
\end{tabular}

宮武 (1998) ${ }^{17)}$ によれば、断層面上で破壊開始点と観測点を結んだ 線分の長さを $l$ 、破壊伝播速度を $v 、 S$ 波速度を $\beta$ とおくと、

$$
l(1 / v-1 / \beta)
$$

と表される。強震動パルスの幅は、破壊開始点と観測点の位置関 係で大きく変動するが、ここでは、各アスペリティの下端から破 壊が開始し、上端付近に観測点が位置している場合、すなわち $l=S_{n}^{0.5}$ の場合を考えてみる。破壊伝播速度として、Geller $(1976)^{36)}$ による経験式、すなわち $v=0.72 \beta$ を採用すると、 $S$ 波速度 $\beta$ は 3.3 $\mathrm{km} / \mathrm{s}$ であるから、最も大きなアスペリティ(asp3 および asp7)か ら生成される強震動パルスの幅は 1.3 秒となり、最も小さなアス ペリティ (asp6) から生成される強震動パルスの幅は 0.6 秒とな る。1994 年米国 Northridge 地震や 1995 年兵庫県南部地震の強震 動パルスの幅は約 0.5 秒であるので、図 4 に示したセグメント 3 の近傍では、これらの地震と同様の強震動パルスの襲来を受ける と推測される。なお、宮武 $(1998)^{17)}$ により計算された強震動パル スは片振幅であるため、その卓越周期はパルス幅の約 2 倍 (例え ば日野, 1977) $)^{37)}$ となる。したがって、いまの例の場合、最も大き なアスペリティから生成される強震動パルスの卓越周期は約 2.6 秒、最も小さなアスペリティから生成される強震動パルスの卓越 周期は約 1.2 秒となる。

各アスペリティの実効応力は、すでに述べたように短周期レべ ルをどのように設定するかによって 0.5〜2倍程度変わるが、地震 モーメントを基準に平均的な短周期レベルを設定すると、126 bar となる。釜江・入倉 $\left.(1997)^{25}\right)$ は、1995 年兵庫県南部地震の強震動 シミュレーションに際して、3 個のアスペリティを設定し、最大 アスペリティの実効応力を $86 \mathrm{bar} 、$ 残りの 2 つのアスペリティの 実効応力を $163 \mathrm{bar}$ と $86 \mathrm{bar}$ と見積もっておう、表 2 に示した実効 応力の値は、これらの值とほほ対応している。また、入倉・釜江 $(1999)^{4)}$ は、1948 年福井地震の強震動シミュレーションに際し て、2 個のアスペリティを設定し、最大アスペリティの実効応力

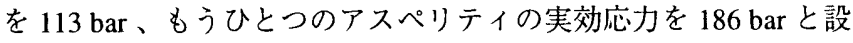
定しており、これらの値も表 2 に示した実効応力の値とおおむね 対応している。これは、短周期レベルと地震モーメントとの平均 的な関係を示す (3) 式が、図 1 (a) に示したように、釜江・入倉 $(1997)^{25)} の 1995$ 年兵庫県南部地震の震源モデルから算定した短周 期レベルと地震モーメントとの関係および入倉・釜江 $(1999)^{4)}$ の 1948 年福井地震の震源モデルから算定した短周期レベルと地震 モーメントとの関係をほほ完全に満たしているからと考えられ る。なお、最近、入倉 $(2000)^{8)}$ は、Somerville et al. $(1999)^{2)}$ により 


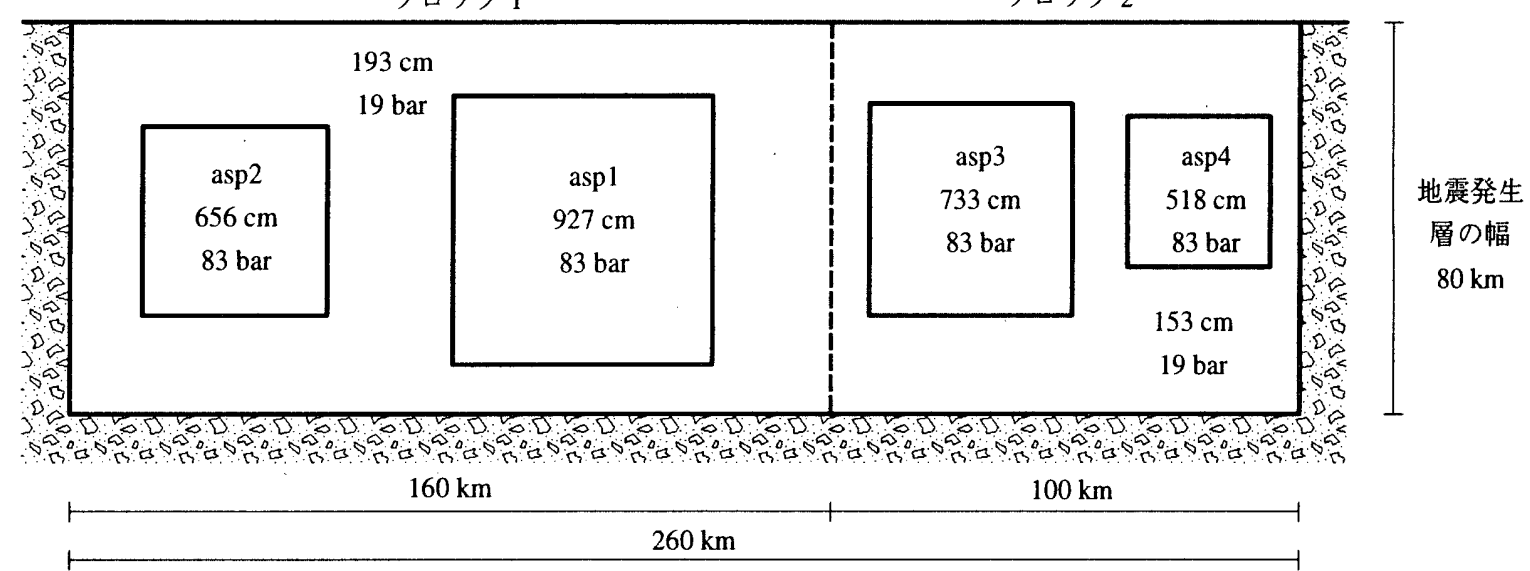

図 5 海溝付近で発生する巨大地震の震源モデルの例

抽出された断層の非一様すべり破壊モデルの統計的特質に基づ き、アスペリティの面積と最終すべり量からアスペリティにおけ る地震モーメントの総和を計算し、各アスペリティの実効応力が 一定となるように、最終すべり量を各アスペリティに再配分して いるが、この場合、セグメントが1つで、そこにアスペリティを

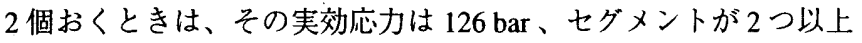
で、各セグメントにアスペリティを1個ずつおくときは、その実 効応力は 96 bar としており、これらの値も、表 2 に示した実効応 力の値と対応している。

\section{3 海溝付近で発生する巨大地震の震源モデルの例}

つぎに、わが国に甚大な被害をもたらしてきたもう一つのタイ プの地震、すなわち海溝付近の巨大地震の震源のモデル化の例と して、プレート境界の 2 つのブロックにわたる低角逆断層を考え てみた。ここに、破壊領域の大きさは、第一ブロックが $160 \mathrm{~km} \times$ $80 \mathrm{~km}$ 、第二ブロックが $100 \mathrm{~km} \times 80 \mathrm{~km}$ とした。したがって、断 層面積は $20,800 \mathrm{~km}^{2}$ である。また、震源における媒質の剪断剛性 率 $\mu$ は $5 \times 10^{11} \mathrm{dyne} / \mathrm{cm}^{2} 、 S$ 波速度 $\beta$ は $4.0 \mathrm{~km} / \mathrm{s}$ とした。

図 3 には、金森 $(1991)^{30)}$ による海溝付近の大地震および巨大地 震の断層面積と地震モーメントとの関係を・で示す。この図か ら、断層面積が $20,800 \mathrm{~km}^{2}$ のとき、平均的な地震モーメントは 4 $\times 10^{28}$ dyne-cm 前後、モーメントマグニチュードで約 8.3 と推定で きる。金森 $(1991)^{30)}$ は、図 3 に・で示したデー夕を含む海溝付近 の地震の断層面積と地震モーメントのデータから、応力降下量を 30 bar として、両者の関係式を定めているが、この式によれば、

表 3 海溝付近で発生する巨大地震の震源パラメータの設定例

\begin{tabular}{lllllll}
\hline & & $M_{0}$ & \multicolumn{1}{l}{$S$} & \multicolumn{1}{l}{$D$} & $\sigma$ & \multicolumn{1}{l}{$\begin{array}{l}\text { dyne-cm } \\
\mathrm{km}^{2}\end{array}$} \\
& & $\mathrm{~cm}$ & bar & dyne-cm/s \\
断層全体 & & $4.00 \times 10^{28}$ & 20800 & 385 & 41 & $8.41 \times 10^{26}$ \\
ブロック 1 & (全体) & $2.68 \times 10^{28}$ & 12800 & 418 & 41 & $6.60 \times 10^{26}$ \\
& (asp1) & $1.38 \times 10^{28}$ & 2987 & 927 & 83 & $5.14 \times 10^{26}$ \\
& (asp2) & $0.49 \times 10^{28}$ & 1493 & 656 & 83 & $3.63 \times 10^{26}$ \\
& (背景) & $0.80 \times 10^{28}$ & 8320 & 193 & 19 & $1.98 \times 10^{26}$ \\
& (全体) & $1.32 \times 10^{28}$ & 8000 & 331 & 41 & $5.22 \times 10^{26}$ \\
& (asp3) & $0.68 \times 10^{28}$ & 1867 & 733 & 83 & $4.06 \times 10^{26}$ \\
& (asp4) & $0.24 \times 10^{28}$ & 933 & 518 & 83 & $2.87 \times 10^{26}$ \\
& (背景) & $0.40 \times 10^{28}$ & 5200 & 153 & 19 & $1.57 \times 10^{26}$ \\
\hline
\end{tabular}

断層面積が $20,800 \mathrm{~km}^{2}$ のとき、地震モーメントは $3.69 \times 10^{28}$ dyne-

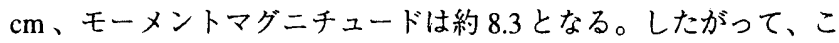
こでは、地震モーメントとして、 $4 \times 10^{28}$ dyne-cm を採用すること にした。この地震モーメントの值を (3) 式に代入すると、平均的 な短周期レベルは $8.41 \times 10^{26} \mathrm{dyne}-\mathrm{cm} / \mathrm{s}^{2}$ と算定できる。

断層全体の地震モーメントと短周期レベルが設定できたので、 自己相似則を仮定して、地震モーメントと短周期レベルを各ブ ロックに配分した。結果を表 3 に示す。

ここで、石井・他 $(2000)^{3)}$ により抽出された震源断層の統計的 特質に基づいて、前出の (52) 式を採用すると、各ブロックごとの アスペリティと背景領域の地震モーメント、面積、平均すべり 量、実効応力、短周期レベルが算定できる。

一方、各アスペリティの面積については、各ブロックで $2 つ の$ アスペリティを考え、第一アスペリティと第二アスペリティの面 積比を $2: 1$ とした。各ブロックにおいて、アスペリティの地震 モーメント $M_{0 a s p}$ と実効応力 $\sigma_{a s p}$ および各アスペリティの面積 $S_{n}$ が設定できたので、これらの值を用いて、(29) 式で常数 $C$ を求め ると、各ブロックに共通な値として、C $=0.552$ が得られた。この 值を(51) 式に代入すると、C[1] として円形クラックの值を用いた 場合、 $\gamma=1.32$ となり、いまの震源モデルの例は、 $N^{1-\gamma=0.64 、 す な ~}$ わち 0.6 個分の円形クラックによる短周期レベルしか有していな いことがわかる。また、C[1]としてアスペリティモデルの値を用 いた場合、 $\gamma=0.400$ となり、 $N^{1-\gamma=2.3 、 す な わ ち ~} 2$ 個の独立なアス ペリティから構成されるアスペリティモデルに置換できることが わかる。

3 章で示した算定式を用いて、各アスペリティの地震モーメン ト、平均すべり量、短周期レベルを求めた。結果をまとめて表 3 に、各アスペリティを正方形として断層面に配置した例を図 $5 に$ 示す。

各アスペリティにより生成されるパルス幅を、宮武(1998) ${ }^{17)}$ に よる (53) 式で計算すると、最も大きなアスペリティ (asp1) から生 成される強震動パルスの幅は 5.3 秒となり、最も小さなアスペリ ティ (asp4) から生成される強震動パルスの幅は 3.0 秒となる。こ こに、前節で述べた内陸で発生する大地震の例と同じく、破壊は 各アスペリティの下端から開始し、上端付近に観測点が位置して いる場合を考え、破壊伝播速度として、Geller (1976) ${ }^{36)}$ による経 験式を採用した。強震動パルスの卓越周期はパルス幅の約 2 倍で 
あるから、いまの例の場合、最も大きなアスペリティ(asp1) から 生成される強震動パルスの卓越周期は約 10 秒、最も小さなアス ペリティ (asp4) から生成される強震動パルスの卓越周期は約 6 秒 となる。Wald and Somerville $(1995)^{19)}$ により同定された 1923 年関 東地震の非一様すべり破壊モデルを用いて、Sato et al. (1999) ${ }^{38)}$ が 計算した震源域における強震動パルスの卓越周期は約 10 秒であ るので、図 5 に示したブロック 1 の近傍では、関東地震と同様の 長周期の強震動パルスの襲来を受けると推測される。

各アスペリティの実効応力は、すでに述べたように短周期レベ ルをどのように設定するかによって $0.5 〜 2$ 倍程度変わるが、地震 モーメントを基準に平均的な短周期レベルを設定すると、表 3 に 示したように、 83 bar となる。この值は、表 2 に示した内陸で発 生寸る大地震のアスペリティに㧍ける実効応力 $126 \mathrm{bar}$ の $1 / 1.52$ と なっているが、これは、(20)式と (21) 式からわかるように、両者 において用いた $S$ 波速度 $\beta$ の差 (実際には $\beta^{2}$ の比で 1/1.47) に主に 起因するものである。

\section{6.まとめ}

本論文では、将来の地震による強震動の予測を、Somerville $e t$ al. $(1999)^{2)}$ や石井 ·他 $(2000)^{3)}$ により抽出された震源断層の統計 的特質に基づいて行うときに必要となる、各アスペリティの実効 応力を算定した。本論文で行った内容および結論をまとめると以 下のようになる。

1) はじめに、これまでに同定されている 12 の内陸地震および 6 つの海溝付近の地震の非一椂すべり破壊モデルから短周期レ ベルを算定した。その結果、短周期レベルは、地震モーメン トの立方根 $M_{0}{ }^{1 / 3}$ でスケーリングできること、また、その平均 的な值は、既往の研究による他の地震の震源モデルから算定 した短周期レベルおよび既往の研究で強震記録から直接評価 された短周期レベルと調和的であることがわかった。ただ し、加藤・他 $(1998)^{23)}$ が指摘しているように、地震モーメン トと短周期レベルとの関係にはかなり地域差があるため、実 際の強震動予測に際しては、この震源域の特性を十分に考慮 する必要がある。

2) つぎに、Somerville et al. (1999) $)^{2)}$ や石井・他 (2000) ${ }^{3)}$ により抽出 された震源断層の統計的特質を有し、かつ非一様すべり破壊 モデルから算定した短周期レベルを有する震源モデルを考 え、各アスペリティおよび背景領域における平均すべり量と 実効応力の算定式を求めた。このときの与条件は、断層全体 の地震モーメント、断層面積、短周期レベル、および各アス ペリティの面積である。

3) 地震モーメントと短周期レベルで規定される本論文での震源 モデルと、Papageorgiou (1988) ${ }^{9)}$ や Gusev (1989) ${ }^{11)}$ などによる 既往の震源モデルとの関係を調べるために、各アスペリティ 間の相互作用の有無を考慮しながら、アスペリティの個数を 変えた場合の検討を行った。その結果、本論文での震源モデ ルは既往の震源モデルに置換できることがわかった。

4) 最後に、わが国に甚大な被害をもたらしてきた内陸の大地震 $\left(M_{W} 7.3\right)$ および海溝付近の巨大地震 $\left(M_{W} 8.3\right)$ の震源のモデル化 の例を示した。例示した内陸の大地震の震源モデルでは、ア スペリティの個数は8個で、各アスペリティにおける実効応力
は 126 bar 、背景領域における実効応力は 29 bar となった。ま た、8 個のアスペリティの間には相互作用が存在し、既往の震 源モデルに置換すると、1 個の円形クラックもしくは 4 個の独 立なアスペリティから構成されるアスペリティモデルに置換 できることがわかった。一方、海溝付近の巨大地震の震源モ デルでは、アスペリティの個数は 4 個で、各アスペリティにお ける実効応力は $83 \mathrm{bar}$ 、背景領域における実効応力は $19 \mathrm{bar}$ と なった。また、円形クラックとしては 1 個分に満たず、アスペ リティモデルとしては2個の独立なアスペリティから構成され るモデルに置換できることがわかった。

本論文では、断層の非一様すべり破壊モデルに基づき、断層面 におけるすべり量もしくは地震モーメントおよび短周期レベルの 統計的特質と整合するように、震源のモデル化を考えた。した がって、震源スペクトルとしては、非一様すべり破壊モデルの震 源スペクトルと同等のものが平均的には再現されていると考えら れるが、実際の強震動の予測問題では、各アスペリティの位置 も、特に、断層近傍における強震動に大きな影響を与える。これ については、現在のところ理論的あるいは経験的な関係は見い出 されていないが、今後、活断層の詳しい調査や地款変動データの 解析などの地球物理学的な研究の蓄積にともない、ある程度の推 定が可能になると期待される。

一方、本論文で用いた短周期レベルの算定式は、壇・佐藤 $(1998)^{1)}$ による推定式であり、この式の妥当性は、既往の研究で 行われた半経験的波形合成法に基づく複数の地震の加速度記録の 再現を通じて、間接的に示されているとして、議論を進めた。し たがって、本論文で算定した短周期レベルとそれぞれの地震の加 速度記録から求められる短周期レベルとを直接比較するなどの検 証が今後必要である。

また、本論文では、現在も研究中との理由で、限界振動数 $f_{\text {max }}$ (例えば Hanks, 1982) ${ }^{18)}$ を震源断層のモデル化に際して考慮しな かった。しかしながら、この值をどう設定するかが非常に短い周 期の地震動の振幅に大きな影響を与えるため、今後、 $f_{\max }$ と断層 破壊メカニズムとの関係を解明する研究が蓄積されれば、その成 果を震源断虜のモデル化に適切に取り入北る必要がある。

\section{謝辞}

本研究をまとめるにあたり、京都大学防災研究所の入倉孝次郎 教授、および 2 名の論文査読委員には、非常に有益なご意見をい ただきました。記してお礼申し上げます。

\section{参考文献}

1) 壇一男・佐藤俊明 (1998): 断層の非一様すべり破壊を考慮した半経験的 波形合成法による強震動予測，日本建築学会構造系論文集，第 509 号， pp. 49-60.

2) Paul Somerville, Kojiro Irikura, Robert Graves, Sumio Sawada, David Wald, Norman Abrahamson, Yoshinori Iwasakai, Takao Kagawa, Nancy Smith, and Akira Kowada (1999): Characterizing crustal earthquake slip models for the prediction of strong ground motion, Seismological Research Letters, Vol. 70 No. 1, pp. 59-80.

3) 石井透・佐藤俊明・Paul G. Somerville (2000): 強震動評価のための不均 質断層モデルの主破壊領域の抽出, 日本建築学会構造系論文集, 第 527 号, pp. 61-70.

4) 入倉孝次郎 - 釜江克宏 (1999): 1948 年福井地震の強震動, 地震, 第 2 輯, 第 52 巻, 第 1 号, pp. 129-150.

5) S. Das and B. V. Kostrov (1986): Fracture of a single asperity on a finite fault, Earthquake Source Mechanics, Maurice Ewing Volume 6, American Geophysical Union, pp. 91-96.

6) John Boatwright (1988): The seismic radiation from composite models of 
faulting, Bulletin of the Seismological Society of America, Vol. 78, No. 2, pp. 489-508.

7) 石井透・佐藤俊明 (2000a): 断層面上の主破壊領域と実効応力のモデル 化に基づく震源近傍強震動評洒の試み，日本建築学会大会学術講演梗 概集 (東北), B-2, 構造 II, pp. 219-220.

8) 入倉孝次郎 $(2000)$ : 最近の大地震における強震動と被害の特徽から学 ぶこと, 大崎総合研究所, 第 7 回和泉イブニングセミナ一, 講演資料。

9) Apostolos S. Papageorgiou (1988): On two characteristic frequencies of acceleration spectra, Bulletin of the Seismological Society of America, Vol. 78 , No. 2, pp. 509-529.

10) Apostolos S. Papageorgiou and Keiiti Aki (1983): A specific barrier model for the quantitative description of inhomogeneous faulting and the prediction of strong ground motion. I. Description of the model, Bulletin of the Seismological Society of America, Vol. 73, No.3, pp. 693-722.

11) A. A. Gusev (1989): Multi-asperity fault model and the nature of short-period subsources, Pure and Applied Geophysics, Vol. 130, No. 4, pp. 635-660.

12) Kazuo Dan and Toshiaki Sato (1998): Simulation of strong ground motions in the near field of the 1979 Imperial Valley, California, earthquake by semiempirical method based on variable-slip rupture model, Proceedings of the 10th Japan Earthquake Engineering Symposium, Vol. 1, pp. 703-708.

13) Kazuo Dan and Toshiaki Sato (1999): A semi-empirical method for simulating strong ground motions based on variable-slip rupture models for large earthquakes, Bulletin of the Seismological Society of America, Vol. 89, No. 1, pp. 36-53.

14）壇一男・佐藤俊明 (1999): 断層の非一様すべり破壊を考慮した半経験的 波形合成法 (その 4), 日本地震学会講演子稿集, No. 2, P010.

15) Keiiti Aki (1967): Scaling law of seismic spectrum, Journal of Geophysical Research, Vol. 72, No. 4, pp. 1217-1231.

16) James N. Brune (1970): Tectonic stress and the spectra of seismic shear waves from earthquakes, Journal of Geophysical Research, Vol. 75, No. 26, pp. 49975009.

17) 宮武隆 (1998): 断層近傍の強震動パルスの成因, 地震, 第 2 輯, 第 51 巻, 第 2 号, pp. 161-170

18) Thomas C. Hanks (1982): fmax, Bulletin of the Seismological Society of America, Vol. 72, No. 6, pp. 1867-1879.

19) David J. Wald and Paul G. Somerville (1995): Variable-slip rupture model of the great 1923 Kanto, Japan, earthquake, Bulletin of the Seismological Society of America, Vol. 85, No. 1, pp. 159-177.

20) Arthur Frankel (1995): Simulating strong motions of large earthquakes using recordings of small earthquakes, Bulletin of the Seismological Society of America, Vol. 85, No.4, pp. 1144-1160.

21）釜江克宏 - 入倉孝次郎・福知保長 (1990): 地域的な震源スケーリング 則を用いた大地震 $(M 7$ 級) のための設計用地震動予測, 日本建築学会構 造系論文報告集, 第 416 号, pp. 57-70.

22）佐藤智美・川桷博・佐藤俊明 (1994): 表層地盤の影響を取り除いた工 学的基盤波の統計的スペクトル特性， 日本建築学会構造系論文集，第 462 号, pp. 79-89.

23）加藤研一 ·武村雅之 ・八代和彦 (1998): 強震記録から評価した短周期 震源スペクトルの地域性, 地震, 第 2 輯, 第 51 巻, 第 1 号, pp. 123-138

24) 釜江克宏 (1996): 1946 年南海地震のシミュレーション, 日本建筑学会, 第 24 回地盤震動シンポジゥム, pp. 81-90.

25）釜江克宏・入倉孝次郎 (1997): 1995 年兵庫県南部地震の断層モデルと 震源近傍に拈りる強震動シミュレーショシ，日本建築学会構造系論文 集, 第 500 号, pp. 29-36.

26）石井透·佐藤俊明 (2000b): 強震動評価のための不均質断層モデルの主 破壊領域の面積とモーメントの関係, 日本地震学会講演予稿集, No. 2, B09.

27) J. D. Eshelby (1957): The determination of the elastic field of an ellipsoidal inclusion, and related problems, Proceedings of the Royal Society of London, Series A, Vol. 241, pp. 376-396.

28) Carlos Mendoza (1993): Coseismic slip of two large Mexican earthquakes from teleseismic body waveforms: Implications for asperity interaction in the Michoacan plate boundary segment, Journal of Geophysical Research, Vol. 98, No. B5, pp. 8197-8210.

29）佐藤良輔編著 (1989): 日本の地震断層パラメター・ハンドブック, 鹿 島出版会.

30) 金森博雄 編 (1991): 地震の物理, 岩波書店.

31）武村雅之 (1998): 日本列島における地款内地震のスケール則, 地震, 第 2 輯, 第 51 巻, 第 2 号, pp. 211-228

32）渡辺基史 ·佐藤俊明・壇一男 (1998): 内陸地震の断層パラメー夕の相 似則，第 10 回日本地震工学シシポジウム, 第 1 分冊, pp. 583-588.

33) 阿部勝征 (1990): フイリピン・ルソン島地震 (1990 年 7 月 16 日) の地震 学的調査, 地震研究所彙報, Vol. 65, pp. 851-873.

34) Donald L. Wells and Kevin J. Coppersmith (1994): New empirical relationships among magnitude, rupture length, rupture width, rupture area, and surface displacement, Bulletin of the Seismological Society of America, Vol. 84, No.4 pp. 974-1002.

35) 松島信一・川瀬博 (2000): 1995 年兵庫県南部地震の複数アスペリティ モデルの提案とそ扎による強震動シミュレーション，日本建筑学会構 造系論文集, 第 534 号, pp. 33-40.

36) Robert J. Geller (1976): Scaling relations for earthquake source parameters and magnitudes, Bulletin of the Seismological Society of America, Vol. 66, No. 5, pp. $1501-1523$.

37) 日野幹雄 (1977): スペクトル解析, 朝倉書店, pp. 22-24.

38) Toshiaki Sato, Robert W. Graves, and Paul G. Somerville (1999): Threedimensional finite-difference simulations of long-period strong motions in the Tokyo Metropolitan area during the 1990 Odawara earthquake $\left(M_{J} 5.1\right)$ and the great 1923 Kanto earthquake $\left(M_{S} 8.2\right)$ in Japan, Bulletin of the Seismological Society of America, Vol. 89, No. 3, pp. 579-607.

39) R. D. Mindlin (1949): Compliance of elastic bodies in contact, Journal of Applied Mechanics, Vol. 16, pp. 259-268.

付録 アスペリティにおけるすべり量と応力降下量およびア スペリティモデルの地震モーメントとの関係

ここでは、Das and Kostrov $(1986)^{5)}$ に準拠して、応力を負担しな い半径 $R$ の円形の背景領域と、その中心から $x(0 \leqq x<R)$ だ離 れた位置にある半径 $r$ の1個のアスペリティから構成されるアス ペリティモデルを考える。また、背景領域と同じ大きさの半径 $R$ の円形クラックを考え、その円形クラックの応力降下量を $\Delta \sigma_{C R}$ とする。このとき、円形クラックのすべり量は、

$$
D_{C R}(x)=(24 / 7 \pi)\left(R^{2}-x^{2}\right)^{1 / 2} \Delta \sigma_{C R} / \mu \quad(0 \leqq x<R)
$$

となる (Eshelby, 1957) ${ }^{27)}$ 。一方、アスペリティにおけるすべり量 を $D_{a s p}(x)$ で一定とすると、応力分布 $\Delta \sigma_{a s p}(x, \rho)$ は、

$$
\Delta \sigma_{a s p}(x, \rho)=(8 / 7 \pi) \mu D_{a s p}(x) /\left(r^{2}-\rho^{2}\right)^{1 / 2} \quad(0 \leqq \rho<r)
$$

となる (Mindlin, 1949) ${ }^{39)}$ 。ここに、 $\rho$ はアスペリティ中心からの 距離である。ここで、応力分布 $\Delta \sigma_{a s p}(x, \rho)$ を半径 $r$ のアスペリ ティ上で平均すると、下式を得る。

$$
\Delta \sigma_{a s p}(x)=(16 / 7 \pi)\left[\mu D_{a s p}(x) / r\right] \quad(0 \leqq x<R)
$$

いま、アスペリティにおけるすべり量 $D_{a, s p}(x)$ と円形クラックの すべり量 $D_{C R}(x)$ とが同じ、すなわち

$$
D_{a s p}(x)=D_{C R}(x) \quad(0 \leqq x<R)
$$

とすると、アスペリティモデルの地震モーメント $M_{0}(x)$ は、Das and Kostrov $(1986)^{5)}$ に示されているように、相反定理を用いて、

$$
\begin{aligned}
M_{0}(x) & =\left(\mu / \Delta \sigma_{C R}\right) \int D_{a s p}(x) \Delta \sigma_{a s p}(x, \rho) 2 \pi \rho d \rho \\
& =(16 / 7)(24 / 7 \pi)^{2}\left(R^{2}-x^{2}\right) r \Delta \sigma_{C R} \quad(0 \leqq x<R)
\end{aligned}
$$

となる。ここに、 $\rho$ に関する積分の区間は $[0, r]$ である。

つぎに、Boatwright (1988) $\left.)^{6}\right)$ と同じく、アスペリティが、半径 $R$ の背景領域の中でランダムに存在する場合を考えて、平均応力

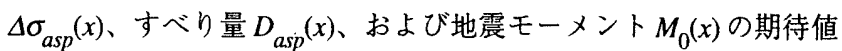
を計算すると、

$$
\begin{aligned}
& \Delta \sigma_{a s p}=(16 / 7 \pi)^{2}(R / r) \Delta \sigma_{C R} \\
& D_{a s p}=(16 / 7 \pi) R \Delta \sigma_{C R} / \mu \\
& M_{0}=(8 / 7)(24 / 7 \pi)^{2} R^{2} r \Delta \sigma_{C R}
\end{aligned}
$$

となる。以上の 3 つの関係式から $\Delta \sigma_{C R}$ を消去すると、

$$
\begin{aligned}
& \Delta \sigma_{a s p}=(16 / 7 \pi)\left(\mu D_{a s p} / r\right) \\
& M_{0}=(18 / 7)(16 / 7 \pi) \mu r R D_{a s p}
\end{aligned}
$$

を得る。 